\title{
Pelatihan Pemanfaatan Kulit Bawang Merah Sebagai Keripik Untuk Menambah Nilai Ekonomi Masyarakat Keluruhan Air Kuti Kecamatan Lubuk Linggau I
}

\author{
Training of the Used Onion Peel Become Crispy Chips To Increase Sociaty Economical \\ Value at Air Kuti, East I Lubuk Linggau \\ Reny Dwi Riastuti ${ }^{1}$, Nopa Nopiyanti ${ }^{2}$, Yulfi ${ }^{3}$, Yuli Febrianti ${ }^{4}$ \\ 1,2,4 Program Studi Pendidikan Biologi, STKIP PGRI Lubuk Linggau, Indonesia \\ ${ }^{3}$ Program Studi Pendidikan Bahasa Inggris, STKIP PGRI Lubuk Linggau, Indonesia \\ Email: ${ }^{1}$ renydwiriastuti09@gmail.com, ${ }^{2}$ nopachandra@gmail.com, ${ }^{3} y$ ulfipatmo@gmail.com, \\ ${ }^{4}$ yuli_febri.anti16@yahoo.co.id
}

\begin{abstract}
Abstrak
Di dalam kulit bawang merah terdapat berbagai senyawa kimia yang sangat bermanfaat bagi tubuh manusia, diantaranya flavanoid, tanin, saponin, dan glikosida. Setiap senyawa tersebut memiliki manfaat yang berbeda, seperti Flavonoid yang dapat menghasilkan aktivitas antioksidan antidermatosis, kemopreventif, antikanker, serta memiliki sifat fotoprotektif sehingga diyakini mampu menyerap sinar ultraviolet. Banyaknya jenis kandungan senyawa kimia tersebut, menjadikan kulit bawang merah dapat diolah menjadi makanan yang sehat dan tinggi gizi. Salah satu produk makanan yang dibuat dari kulit bawang merah adalah keripik. Pelatihan ini bertujuan untuk memperkenalkan produk keripik kulit bawang merah kepada ibu-ibu PKK di kelurahan Air Kuti Lubuklinggau Timur I. Metode pelaksanaan dalam pengabdian ini adalah pelatihan yang dimulai dari tahap sosialisasi, tahap pemberian pengetahuan, dan tahap pelatihan. Lokasi Pelaksanaan program PKM ini adalah di kelurahan Air Kuti, Kecamatan Lubuklinggau Timur 1, Kota Lubuklinggau Sumatera Selatan. Hasil dari kegiatan ini adalah: 1) ibu ibu PKK kelurahan Air Kuti setelah mengikuti pelatihan menjadi tau akan kandungan dalam kulit bawang merah, 2) Ibu ibu PKK kelurahan Air Kuti setelah mengikuti pelatihan menjadi bisa mengolah dan membuat kulit bawang merah menjadi kerikpik kulit bawang merah, 3) Bertambahnya variasi makanan, yaitu keripik kulit bawang merah dengan berbagai rasa pada industri rumah tangga di daerah Mitra

Kata kunci-Pelatihan, keripik, kulit bawang merah
\end{abstract}

\begin{abstract}
Onion peel contains various chemical compounds which are good for human body, including flavonoids, tannins, saponins and glycosides. Each of them have different benefit, such as Flavonoids that can produce anti-dermatosis, chemopreventive, anticancer, antioxidant activity, and have photoprotective properties so they can absorb ultraviolet. The many types of chemical compounds make onion peel can be made into healthy and high nutrient foods. One of them is red onion peel chips. The objective of this program is to introduce red onion peel chips to members of PKK in Air Kuti sub-district of East Lubuklinggau.I Implementation method of this program is giving training which is started with socialization, knowledge sharing, and the last is training. This program is located at Air Kuti Village, East Lubuklinggau 1. The results shows that:: 1) members of PKK at Air Kuti sub-district after participating in the training are become aware of the content in the onion peel. 2. They can make red onion peels into delicious chips. 3. Increasing the variety of food, namely red onion peel chips with various flavors in home industry especially at the Mitra area
\end{abstract}

Keyword-training, chips, onion peel

\section{PENDAHULUAN}

Tanaman bawang merah dengan nama latin (Allium Cepa) adalah tanaman monokotil semusim, yang memiliki modifikasi batang berupa umbi lapis, dan akar berupa serabut, dengan bentuk daun panjang berongga. Tanaman ini yang termasuk ke dalam famili Alliaceae, 
(suratiyah, 2011). Bawang merah merupakan tanaman lokal yang banyak ditemukan di Indonesia. Umbi bawang merah dapat dimakan secara langsung, dijadikan sebagai bumbu masakan, obat tradisional, dan lain-lain, (Ilham, 2020). Manfaat dari tanaman bawang merah ini sangat banyak, antara lain dijadikan sebagai obat tradisional dan bumbu masakan. Menurut Wibowo (2019) tanaman bawang merah sudah lama dimanfaatkan oleh masyarakat. Zaman dulu masyarakat menggunakan tanaman bawang merah untuk mengobati rasa nyeri perut, untuk menyembuhan luka atau infeksi, untuk menyembuhkan penyakit Diebetes (kencing manis) dan bisa juga digunakan sebagai obat demam. Bawang merah (Allium cepa) juga merupakan alah satu tanaman yang dapat digunakan sebagai antiinflamasi. Tanaman bawang merah mempunyai kaya kandungan yang bermanfaat bagi tubuh, antara lain senyawa flavonoid (rutin dan kuersetin) yang bisa digunakan sebagai antiinflamasi (Filomenaet al,2007). Pada beberapa penelitian telah diketahui bahwa pada kulit bawang merah memiliki kandungan senyawa kimia yaitu: Fraksi etil asetat yang mengandung flavonoid, polifenol dan alkaloid, Fraksi air yang mengandung flavonoid, polifenol, saponin, terpenoid dan alkaloid.. Fraksi n-heksana mengandung saponin, steroid dan terpenoid, (Siti, 2015).

Hasil penelitian Soebagio (2007) menyatakan bahwa ekstrak kulit bawang merah memiliki kandungan senyawa kimia yang bagus untuk kekebalan tubuh, berpotensi sebagai antioksidan yaitu flavonoid yang dapat mencegah berkembangnya radikal bebas di dalam tubuh dan dapat memperbaiki sel-sel tubuh yang telah rusak. Hasil penelitian Rodriues (20017) menyatakan bahwa Kulit bawang merah memiliki kandungan kimia yang berkhasiat sebagai anti kanker dalam sistem regulasi sel, berinteraksi dengan reseptor estrogen (ER) tipe II serta menghambat tumbuhnya enzim tirosin kinase. Selain itu kandungan pada kulit bawang merah juga terdapat protein, mineral, sulfur, antosianin, kaemferol, karbohidrat, dan serat. Dalam penelitian Tina dkk (2017) disebutkan juga bahwa tanaman kulit bawang merah memiliki sifat fotoprotektif sehingga mampu menyerap sinar ultraviolet.

Tanaman bawang merah setelah melalui pasca panen, akan di sortir dahulu. Pembersihan dari tanah dan akar serta kulit terluar bawang merah yang kering akan dibuang terlebih dahulu agar penampilan bawang merah terlihat segar dan memiliki nilai yang tinggi. Sebelum dijual kepada konsumen dipasar beberapa tengkulak akan mengsortir kembali bawang merah ini, sehingga di dapatkan banyak limbah kulit bawang merah.

Melihat banyaknya kandungan dan manfaat yang terdapat pada kulit bawang merah, hal ini perlu ditindaklanjuti untuk disosialisasikan kepada masyarakat agar bisa menambah nilai ekonomi dari kulit bawang tersebut.

Di Lubuklinggau kulit bawang merah selama ini tidak dimanfaatkan dan dianggap sebagai sampah. Di beberapa pasar yang ada di Lubuklinggau, kulit bawang merah ini dibuang, karena masyarakat tidak mengetahui manfaat dari kulit bawang merah tersebut. Salah satu cantoh pemanfaatan kulit bawang merah adalah dapat diolah sebagai makanan yang sehat dan bergizi. Salah satu olahan kulit bawang merah yang bisa dijadikan sebagai makanan atau cemilan sehat adalah keripik kulit bawang merah.

Keripik merupakan makanan ringan atau camilan berupa irisan tipis yang sangat populer di kalangan masyarakat karena sifatnya yang renyah, gurih, tidak terlalu mengenyangkan dan tersedia dalam aneka rasa seperti asin, pedas dan manis. Keripik sangat praktis karena kering, sehingga lebih awet dan mudah disajikan kapan pun. Keripik kulit bawang merah merupakan camilan sehat yang terbuat dari bahan alami. Kehadiran keripik kulit bawang merah selain dapat dijadikan sebagai upaya pengurangan limbah kulit bawang merah itu sendiri, makanan ringan ini juga menjadi salah satu langkah untuk menciptakan kreasi baru dan dapat dijadikan alternatif peluang bisnis keluarga.

Pada saat ini, di Kelurahan Air Kuti khususnya di daerah Pemberdayaan Kesejahteraan Keluarga (PKK) Dasa Wisma 4 telah memiliki beberapa industri rumah tangga yang berproduksi pada pengolahan pangan, namun produk yang dihasilkan kurang kreatif. Produk pangan yang selama ini dihasilkan seperti kerupuk jengkol, kerupuk bombai, kerupuk makaroni, dan keripik pisang. Hal inilah yang mendasari kegiatan PKM ini, yaitu memperkenalkan produk

Pelatihan Pemanfaatan Kulit Bawang Merah Sebagai Keripik Untuk Menambah Nilai Ekonomi Masyarakat Kelurahan Air Kuti Kecamatan Lubuk Linggau (Reny Dwi Riastuti, Nopa 
olahan baru yang juga dapat dijadikan sebagai usaha memperbaiki dan meningkatkan perekonomian rumah tangga.

\section{METODE PELAKSANAAN}

Metode pelaksanaan PKM ini adalah dengan melaksanakan pelatihan pemberdayaan kepada masyarakat melalui limbah kulit bawang merah. Hal tersebut dilakukan dengan melakukan beberapa metode dan waktu pelaksanaan sesuai dengan jadwal yang telah dipersiapkan saat pelaksaan berlangsung. Pelatihan ini telah dilaksanakan di Kelurahan Air Kuti Kecamatan Lubuklinggau Timur 1, Kota Lubuklinggau.

Peserta pelatihan terdiri dari ibu-ibu PKK Dasa Wisma 4 dan beberapa tim yang memiliki usaha home industri yang dibimbing langsung oleh pendamping dalam kesempatan ini adalah dosen agar pelatihan berjalan dengan efektif. Kegiatan ini bekerjasama dengan Pembina PKK Dasa Wisma kelurahan Air Kuti, Lubuklinggau Timur 1 sebagai jembatan langsung agar target luaran dapat tercapat secara maksimal.

Adapun dalam pelaksanaannya, pelatihan ini diawali dengan persiapan pelaksanaan. Pertama meminta surat izin pelaksanaan dari Lembaga Pembelajaran, Penelitian dan Pengabdian Kepada Masyarakat (LP3) STKIP PGRI Lubuklinggau. Setelah mendapatkan ijin, pengurusan perijinan pun berlanjut ke kelurahan Air Kuti. Setelah perizinan selesai, tahapan selanjutnya adalah pelaksanaan Pelatihan Pembuatan Keripik Kulit Bawang Merah ke ibu-ibu PKK Dasa Wisma 4 dan beberapa tim yang memiliki usaha home industri Kelurahan Air Kuti, Kecamatan Lubuklinggau Timur I, Kota Lubuklinggau. Pelatihan ini terdiri dari:

a. Tahap Pemberian Pengetahuan

Pemberian pengetahuan dasar kepada ibu PKK dan tim home industri diwakili oleh ketua PKK Dasa Wisma Kelurahan Air Kuti. Kemudian pengetahuan terkait materi pokok pelatihan mengenai: Memberikan pengetahuan tentang kandungan kulit bawang merah, dan memberikan pengetahuan tentang peluang industri rumah tangga diberikan oleh tim pelaksana pelatihan.

Kegiatan ini melibatkan narasumber yang berasal dari dosen-dosen dan disesuaikan dengan keahlian dibidang masing-masing dosen sehingga dapat saling melengkapi dan berbagi pikiran dan pengetahuan. Pelatihan ini dilaksanakan selama 3 hari.

b. Tahap Sosialisasi Program

Pada tahap ini, diadakan sosialisasi tentang kandungan dan pemanfaatan kulit bawang merah yang diolah menjadi keripik sebagai cemilan sehat dan tinggi gizi di kelurahan Air Kuti.

c. Tahap Pemberian Pelatihan pembuatan keripik kulit Bawang Merah

Setelah diberikan sosialisasi tentang kandungan dan pemanfaatan kulit bawang merah, tim yang terdiri dari empat dosen mulai memberikan pelatihan tentang proses pembuatan keripik kulit bawang merah. Dari tahapan persiapan, penyiapan bahan, proses memasak hingga mengemas produk dan pemasaran dibahas pada tahapan ini.

Tujuan pelatihan pembuatan keripik kulit bawang merah ini adalah untuk menambah variasi produk pangan yang dijual oleh industri rumah tangga. Evaluasi dilakukan dengan mengamati kinerja para peserta. Setelah pelatihan, tim mempersilahkan para peserta untuk melakukan tahapan pembuatan keripik secara mandiri. Tim memantau kinerja mulai dari proses hingga produk keripik yang dihasilkan. Indikator pencapaian yang ditetapkan adalah, bahwa pengabdian dinyatakan berhasil apabila masing-masing peserta sudah bisa membuat keripik kulit bawang merah.

\section{HASIL DAN PEMBAHASAN}

Bawang merah merupakan jenis umbi yang biasanya dipakai sebagai bumbu olahan makanan. Bawang merah juga sudah banyak dikenal oleh masyarakat Indonesia. Limbah kulit 
bawang merah yang selama ini tidak dimanfaatkan dan dianggap sebagai sampah ternyata dapat diolah menjadi produk makanan atau cemilan yang sehat dan tinggi gizi. Berdasarkan hasil penelitian Octaviani dkk, 2019 tentang skrining fitokimia, ekstrak tanaman kulit bawang merah mengandung senyawa, terpenoid, fenolik, dan flavonoid yang dapat menghambat pertumbuhan mikroorganisme. Sehingga kulit bawang merah cocok dijadikan sebagai keripik cemilan sehat. Hal ini tidak perlu dikawatikan masalah minyak karena sesuai dengan penelitian Farich 2013 mengatakan bahwab Semakin banyak penambahan ekstrak bawang merah semakin optimal dalam penundaan oksidasi minyak dengan semakin menurunnya aroma khas minyak jelantah dan kekeruhannya.

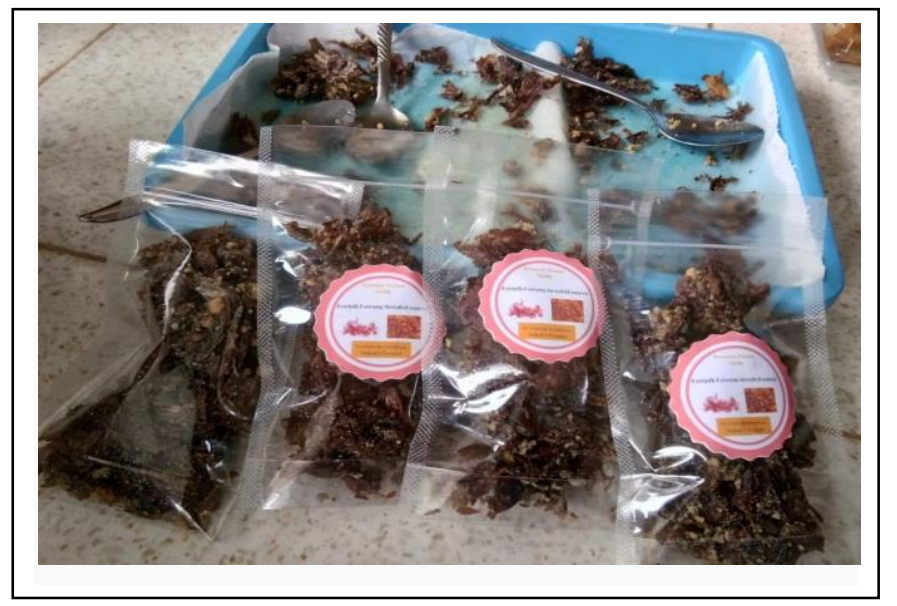

Gambar 1. Produk jadi keripik kulit bawang merah

Selama kegiatan berlangsung, peserta terlihat antusias dalam mengikuti pelatihan dari setiap acara. Dengan metode ceramah dan diskusi ringan, diharapkan mampu membantu ibu-ibu yang notabene-nya merupakan ibu rumah tangga dalam memahami materi pelatihan yang disampaikan dengan mudah. Kegiatan pelatihan pun dilaksanakan dengan santai, bertempat di teras rumah ketua PKK Dasa Wisma.

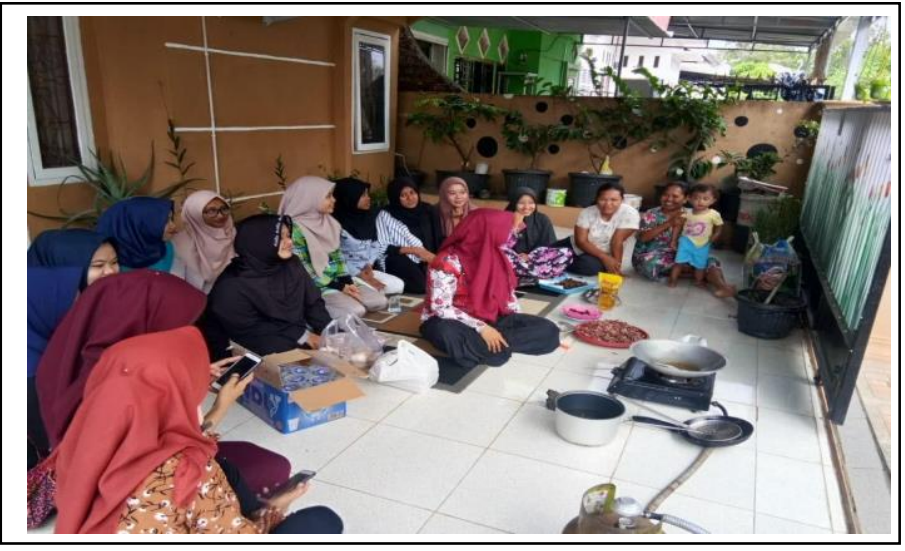

Gambar 2. Pelaksanaan pelatihan di teras rumah ketua PKK Dasa Wisma

Pelatihan dilaksanakan selama 3 (tiga) hari dengan rincian kegiatan: a) Hari I : presentasi materi 1 tentang pengetahuan kandungan kulit bawang merah disampaikan Reny Dwi Riastuti, M.Pd.Si, dan materi 2 tentang peluang industri rumah tangga yang disampaikan oleh Nopa Nopiyanti, M.Pd.Si. Materi selanjutnya terkait Peluang Keripik Kulit Bawang Merah sebagai produk kreatif terbaru disampaikan oleh Yulfi, M.Pd, dan Yuli Febrianti, M.Pd.Si. Kemudian dilanjutkan dengan tanya jawab, dan diskusi. b) Hari 2 adalah pelatihan pembuatan 
keripik kulit bawang merah kepada ibu PKK Kelurahan Air Kuti. Kegiatan ini dipandu oleh seluruh dosen. Dan c) Hari ke 3, pelatihan pendalaman pembuatan keripik kulit bawang merah khusus kepada ibu-ibu yang memiliki industri rumah tangga.

Kegiatan pelatihan ini juga dipublikasikan di media masa Linggau Pos. Adapun tujuan ini adalah agar lebih banyak warga yang mengetahui manfaat dari kulit bawang merah serta menjadikan peluang usaha.

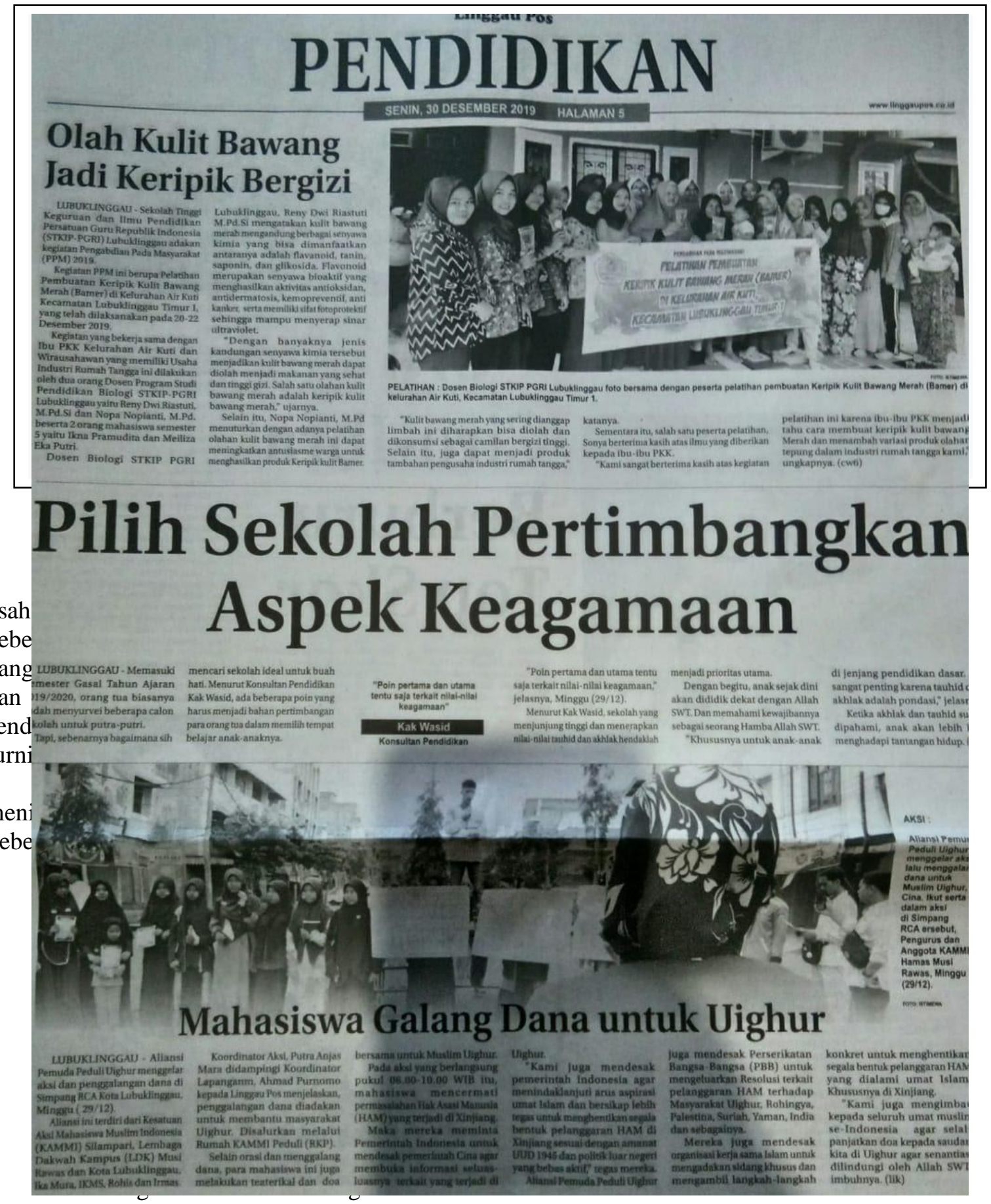

12. Belajar Pengetahuan Tentang Bisnis

13. Kreativitas yang Tinggi

14. Bisa Dijalani Oleh Pemula

15. Mengurangi Angka Pengangguran 
Dari pertimbangan kriteria di atas, jenis bisnis yang tepat adalah Keripik kulit bawang merah. Hal ini karena minat pasar/warga dari berbagai kalangan menyukai jenis makanan/cemilan berupa keripik yang memiliki kandungan gizi yang tinggi, kemudian modal yang dikeluarkan juga tidak terlalu banyak. Bahan utama bisa didapatkan secara gratis di pasar-pasar. Visi dalam menjalankan industri rumah tangga adalah untuk menambah penghasilan bisa terpenuhi

\section{KESIMPULAN}

Berdasarkan hasil pelaksanaan Program PPM yang bertema Pelatihan pembuatan Keripik kulit Bamer (Bawang Merah) di kelurahan Air Kuti, Kecamatan Lubuklinggau Timur 1, dapat disimpulkan bahwa Ibu ibu PKK kelurahan Air Kuti setelah mengikuti pelatihan menjadi tau akan kandungan dalam kulit bawang merah. Ibu ibu PKK kelurahan Air Kuti setelah mengikuti pelatihan menjadi bisa mengolah dan membuat kulit bawang merah menjadi kerikpik kulit bawang merah. Bertambahnya variasi makanan, yaitu keripik kulit bawang merah dengan berbagai rasa pada industri rumah tangga di daerah Mitra.

\section{UCAPAN TERIMAKASIH (Jika Ada)}

Terimakasih kepada kampus STKIP PGRI Lubuklinggau yang telah memberikan biaya dalam pelaksanaan pengabdian ini.

\section{DAFTAR PUSTAKA}

Farich Mochamad Alfi Zahwanul, Hengky Hardianto, Aulia Rahmawati. Pengaruh Ekstraksi Bawang Merah, Pengaturan Karakteristik Fisis, dan Mekanis Terhadap Kualitas Minyak Jelantah Konvensional. Proceedings of Seminar Nasional Fisika, Universitas Negeri Surabaya, 1-5 (2013)

Fitria Dewi Sulistiyono, Trirakhma Sofihidayati dan Bina Lohitasari. 2018. Uji aktivitas antibakteri dan fitokimia kulit bawang Merah (Allium cepa) Hasil ekstraksi metode Microwave Assisted Extraction (MAE). Mandala of Health a Scientific Journal. Vol.11, No.2, (71-79).

Filomena, C., Silvio, Mariangela, Federica, Giancarlo, Dimitiar, Aurelia, Francesco and Roberto. 2008. In vivo Anti inflammatory and In Vitro Antioxidant Activities of Mediterranean Dietary Plants. Journal Of Ethnophamracology :144-151.

Ilham Muhammad, Sumarni. 2020. Ekstraksi Antosianin Dari Kulit Bawang Merah Sebagai Pewarna Alami Makanan (Variabel Volume Pelarut Dan Kecepatan Pengadukan)Jurnal Inovasis Proses. Vol.5, No 1 (27-32).

Octaviani M, Fadli H, Yuneistya. 20019. Uji Aktivitas Antimikroba Ekstrak Etanol dari Kulit Bawang Merah(Allium cepa L.) dengan Metode Difusi Cakram. Journal Pharmaceutical Science Research. Vol. 6, No 1 (62-68).

Soebagio, B., Rusdiana, T. dan Khairudin. 2007. Pembuatan Gel dengan Aqupec HV-505 dari Ekstrak Umbi Bawang Merah (Allium cepa,L.) sebagai Antioksidan. Fakultas Farmasi, Universitas Padjadjaran. Bandung

Rodriguez-Martinez H. 2007. State of the art in farm animal sperm evaluation. Reprod Fertil Dev 19: 91-101.

Suratiyah. 2011. Ilmu usahatani. Jakarta: Penebar Swadaya.

Siti Rahayu, Nunung Kurniasih, Vina Amalia. Ekstraksi dan Identifikasi Senyawa Flavonoid dari Limbah Kulit Bawang Merah sebagai Antioksidan Alami. Jurnal al-Kimiya Vol 2 No.1 2015

Pelatihan Pemanfaatan Kulit Bawang Merah Sebagai Keripik Untuk Menambah Nilai Ekonomi Masyarakat Kelurahan Air Kuti Kecamatan Lubuk Linggau (Reny Dwi Riastuti, Nopa 
Tina Dwi Rahayu, Mirhansyah Ardana, Laode Rijai. 2017. Potensi Kuli Bawang Merah (Allium cepa l) Sebagai Antoksidan dan Tabir Surya. Proceeding Mulawarman Pharmaceuticals Conferences. 84-89

Wibowo, S. 2009. Budidaya Bawang Putih, Merah dan Bombay. Penebar Swadaya, Jakarta. 